
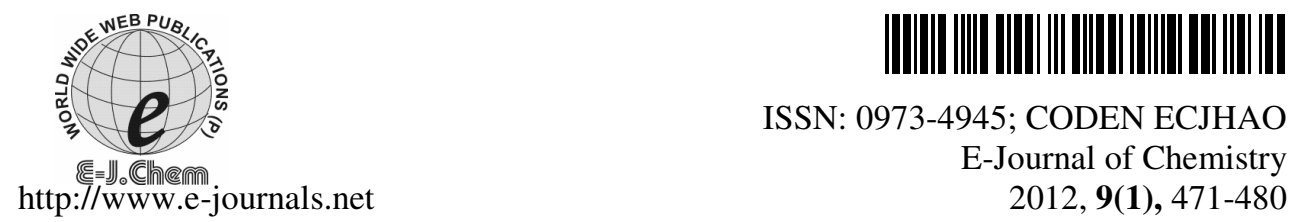

ISSN: 0973-4945; CODEN ECJHAO

E-Journal of Chemistry 2012, 9(1), 471-480

\title{
Interaction of Anticancer Drug Methotrexate with DS-DNA Analyzed by Spectroscopic and Electrochemical Methods
}

\author{
R. HAJIAN* ${ }^{*}$ and M. TAVAKOL \\ *Young Researchers Club \\ Gachsaran Branch, Islamic Azad University \\ Gachsaran, Iran \\ Gachsaran Branch, Islamic Azad University \\ Gachsaran, Iran \\ hajian@iaug.ac.ir
}

Received 28 April 2011; Accepted 3 July 2011

\begin{abstract}
Cyclic voltammetry coupled with UV/Vis spectroscopic techniques were used to study the interaction of methotrexate (MTX), an antitumor drug, with double stranded fish sperm DNA (ds-DNA) in phosphate buffer solution $(\mathrm{pH}$ 7.4). The interaction of MTX with DNA could result a considerable decrease in the MTX peak current. The variations in the spectroscopy and electrochemical characteristics of MTX indicated MTX bind to DNA by a groove binding mode. This conclusion was reinforced by viscosity data. The apparent transfer coefficients $(\alpha)$ and the number of electron transferred (n) of methotrexate in the absence and preset of ds-DNA have determined using anodic Tafel plots of MTX and MTX-DNA adduct on the surface of glassy carbone electrode. The diffusion coefficients of MTX in the absence $\left(\mathrm{D}_{0}\right)_{\mathrm{f}}$ and presence $\left(\mathrm{D}_{0}\right)_{\mathrm{b}}$ of DNA were calculated as $7.30 \times 10^{-6}$ and $3.40 \times 10^{-6} \mathrm{Cm}^{2} \mathrm{~s}^{-1}$ respectively. In spectrophotometric studies, the slopes of the calibration curves for methotrexate in the absence and presence of ds-DNA differ significantly. These studies are valuable for a better understanding the detailed mode of MTX-DNA interaction, which should be important in deeper insight into the therapeutic efficacy of MTX and design of new DNA targeted drug.
\end{abstract}

Keywords: Methotrexate, Double Stranded DNA, Interaction, Spectrophotometry, Electrochemistry

\section{Introduction}

In the last decades, much attention was paid to the binding of small molecules with DNA, as a result of decided advantages of these molecules as potential drugs. Many natural or synthetic 
drugs serve as analogues in the research of protein-nucleic acid recognition and provide sitespecific reagents for molecular biology. Therefore, the investigation of drug-DNA interaction is important for understanding the molecular mechanisms of the drug action and designing specific DNA-targeted drug ${ }^{1}$. Since the concept of intercalation into DNA was first formulated by Lerman in $1961^{2}$. It has become widely recognized that many compounds of pharmacological interest, including anticancer drugs and antibiotics correlate their biological and therapeutic activities with the ability of intercalative interaction with $\mathrm{DNA}^{3}$. This noncovalent binding has an important function in life phenomena at the molecular level, deciding the interaction specificity of drug with DNA.

Methotrexate ((2S)-2-[(4-\{[(2,4-diaminopteridin-6-yl) methyl] (methyl) amino $\}$ phenyl) formamido] pentanedioic, see Figure 1) is a drug included into the antineoplastic and antireumatic therapeutic categories. It belongs to antifolates which produced the first striking, although temporary remission in leukemia and the first cure of a solid tumor, choriocarcinoma ${ }^{4-8}$. There has not yet any report about the detection of the MTX-DNA interaction based on the electrochemical behaviors at a glass carbon electrode (GCE) and especially on the change of various spectroscopic characteristics. Accordingly, in this work, detailed investigations of the electrochemical behavior of MTX upon addition of DNA were carried out. Moreover, the changes in the electronic absorption spectra, fluorescence emission spectra and viscosity when MTX binding to DNA were used to study the mode of such interaction. The agreement of the various methods is quite good. Thus it can be seen, there is a mutual complement between electrochemical method and spectroscopy techniques, which can provide fruitful information about the mechanism of interaction and the conformation of adduct from different aspects.<smiles>CN(Cc1cnc2nc(N)nc(N)c2n1)c1ccc(C(=O)N[C@@H](CCC(=O)O)C(=O)O)cc1</smiles>

Figure 1. Chemical structure of methotrexate

As a planar dye molecule, methylene blue (MB) has long been used for biological staining and diagnosis of disease including carcinoma $1^{9-14}$. It is a phenothiazinyl dye, which is a kind of photosentizer drug molecule showing promising applications to the photodynamic therapy (PDT) for anticancer treatment ${ }^{15}$. The interaction of methylene blue with DNA has been studied with various methods ${ }^{16-20}$. Most studies have indicated that at low ionic strength buffer and low concentration of DNA the major binding mode of MB with DNA is through intercalation. Moreover, no evidence shows that MB is a carcinogenic compound $^{21}$. In this research, methylene blue has used as a probe for study the interaction mechanism of methotrexate with ds-DNA. 


\section{Experimental}

Methotrexate and fish sperm DNA (Sigma, USA) were used without further purification. The MTX stock solution of $1.0 \times 10^{-3} \mathrm{~mol} \mathrm{~L}^{-1}$ was kept away from light to avoid photochemical decomposition and was diluted just before using. The stock solution of methylene blue $\left(1.0 \times 10^{-3} \mathrm{~mol} \mathrm{~L}^{-1}\right)$ was prepared from a MB $(99.5 \%$, Aldrich) and kept in a refrigerator at $4{ }^{\circ} \mathrm{C}$. The concentration of DNA $\left(1.38 \times 10^{-3} \mathrm{~mol} \mathrm{~L}^{-1}\right.$, base pairs) was spectroscopically determined using molar absorption coefficient of $13200 \mathrm{~cm}^{-1}$ $\mathrm{mol}^{-1} \mathrm{dm}^{3}$ at $260 \mathrm{~nm}$. The phosphate buffer $\left(0.1 \mathrm{~mol} \mathrm{~L}^{-1}\right)$ was prepared by adjusting $\mathrm{pH}$ of the solution with $\mathrm{NaOH}$. If not specially stated, the supporting electrolyte was a mixture of phosphate buffer $\left(0.1 \mathrm{~mol} \mathrm{~L}^{-1}, \mathrm{pH} 7.4\right)$ and sodium chloride $\left(0.1 \mathrm{~mol} \mathrm{~L}^{-1}\right)$. All reagents were analytical grade and aqueous solutions were prepared using doubly distilled deionized water.

The absorption spectra were recorded on a Lamda 25 spectrophotometer (Perkin Elmer) and the Electrochemical studies were recorded using an Autolab instrument, Model PGSTAT 30 processor, with three electrodes consisting of a Glassy Carbon as a working electrode, an $\mathrm{Ag} / \mathrm{AgCl}\left(3.0 \mathrm{~mol} \mathrm{~L}^{-1} \mathrm{KCl}\right)$ reference electrode and a carbon counter electrode that linked to a computer (Pentium IV, $2.0 \mathrm{GHz}$ ).

Viscosity measurements were performed using viscometer (model SVM 3000) from Ancontaar Company, which were immersed in a thermostat water-bath at room temperature. Different amount of DNA was then added into the viscometer while keeping the MTX concentration constant. The flow times of the samples were repeatedly measured with an accuracy of $\pm 0.20 \mathrm{~s}$ by using a digital stopwatch. The data were presented as $\left(\eta / \eta_{0}\right)$ versus $\mathrm{C}_{\mathrm{DNA}} / \mathrm{C}_{\mathrm{MTX}}$ ratio, where $\eta$ and $\eta_{0}$ are the viscosity of MTX in the presence and absence of DNA, respectively.

\section{Results and Discussion}

\section{The electronic absorption spectra of MTX in the presence of DNA}

UV - visible spectroscopy is the most common and convenient way to study the interaction between small molecules or rare earth complexes and nucleic acid. Molecules containing aromatic or phosphate chromophore groups can interact with double helix structure of DNA, therefore, the interaction between them can be researched according to changes in the absorption spectra before and after of reaction. Red shift (or blue shift), hyperchromic (or hypochromic) effects and isochromatic point are spectral properties of DNA-drug interaction, which closely related with the double helix structure ${ }^{22}$. Generally, red shift (or blue shift) and hypochromic (or hyperchromic) effect are observed in the absorption spectra if molecules intercalate with DNA. Hypochromic effect is obvious if the intercalation is strong $^{23,24}$.

In this work, UV-Vis spectrophotometric titration of a solution containing MTX with the concentration of $5.0 \times 10^{-5} \mathrm{~mol} \mathrm{~L}^{-1}$ were recorded by double stranded DNA (ds-DNA) solution. The results in Figure 2 show three absorption bands at $256 \mathrm{~nm}, 305 \mathrm{~nm}$ and $368 \mathrm{~nm}$ for MTX in the absence of DNA. Increasing the DNA concentration to the solution of MTX does not change the intensity of the absorption bands at $256 \mathrm{~nm}$ and $305 \mathrm{~nm}$. Also the calibration curves of DNA at $256 \mathrm{~nm}$ in the absence and presence of methotrexate do not differ in slope significantly (Figure 3). It shows that a small molecule such as MTX could not affected on the structure of ds-DNA. 


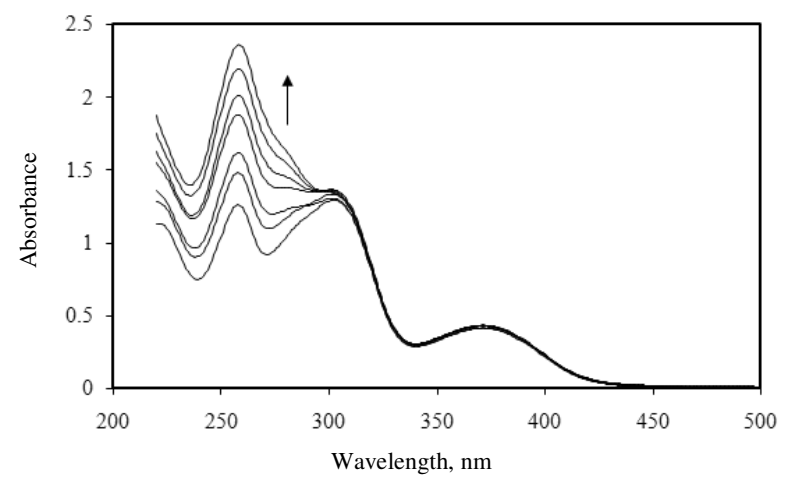

Figure 2. Absorption spectra of MTX in the presence of DNA in different concentrations. $\mathrm{C}_{\mathrm{DNA}}=0.0,27.6,55.3,82.9,110.6,138.2$ and $165.8 \mu \mathrm{mol} \mathrm{L}^{-1}$ for curves $1-7$ and $\mathrm{C}_{\mathrm{MTX}}=50.0 \mu \mathrm{mol} \mathrm{dm}{ }^{-3}$ in phosphate buffer $\left(0.1 \mathrm{~mol} \mathrm{~L}^{-1}, \mathrm{pH} 7.4\right)$ plus $\mathrm{NaCl}\left(0.1 \mathrm{~mol} \mathrm{~L}^{-1}\right)$

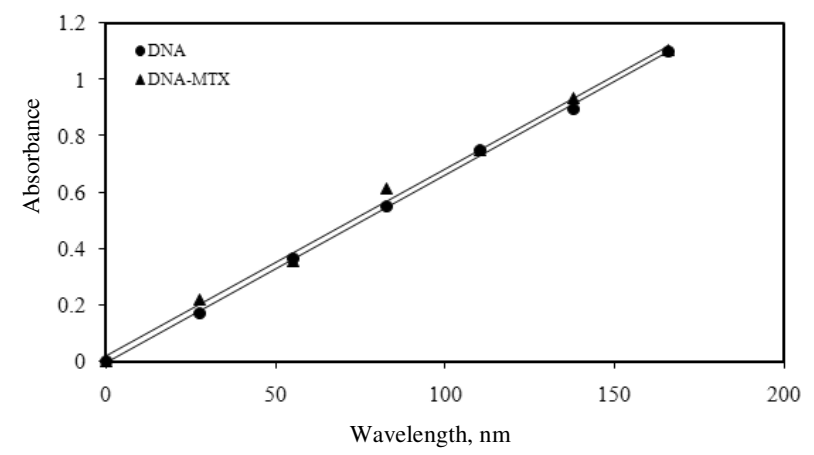

Figure 3. Calibration curves for DNA in the absence and presence of MTX at $260 \mathrm{~nm}$. Conditions: phosphate buffer $\left(0.1 \mathrm{~mol} \mathrm{~L}^{-1}, \mathrm{pH}\right.$ 7.4) plus $\mathrm{NaCl}\left(0.1 \mathrm{~mol} \mathrm{~L}^{-1}\right), \mathrm{C}_{\mathrm{MTX}}=50.0 \mu \mathrm{mol} \mathrm{L}^{-1}$

Furthermore the UV-vis absorption spectra have recorded by titration of $100 \mu \mathrm{mol} \cdot \mathrm{L}^{-1}$ ds-DNA solution with MTX (Figure 4). As it has shown in Figure 5, the slopes of two calibration curves for methotrexate at $256 \mathrm{~nm}$ are significantly differ with each other in the absence and presence of ds-DNA due to interaction between MTX-DNA adduct.

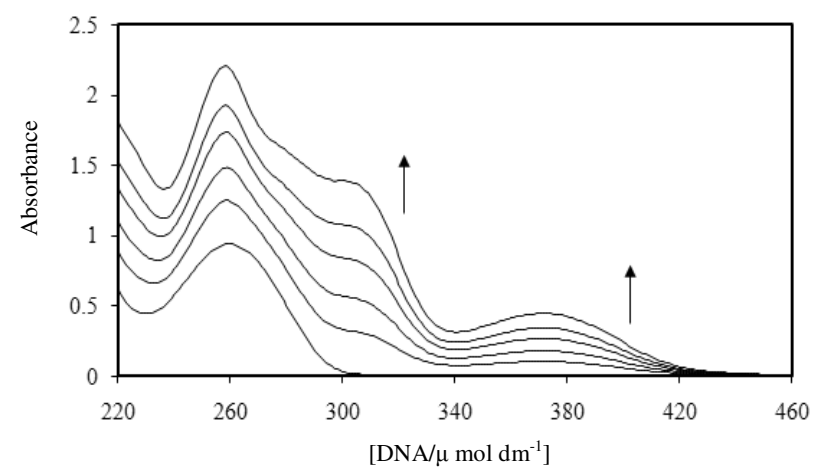

Figure 4. Absorption spectra of DNA in the presence of MTX in different concentrations. $\mathrm{c}_{\mathrm{MTX}}=0.0,10.0,20.0,30.0,40.0$ and $50.0 \mu \mathrm{mol} \mathrm{L}{ }^{-1}$ for curves $1-6$ and $\mathrm{C}_{\mathrm{DNA}}=50.0 \mu \mathrm{mol} \mathrm{L}$ in phosphate buffer $\left(0.1 \mathrm{~mol} \mathrm{~L}^{-1}, \mathrm{pH} 7.4\right)$ plus $\mathrm{NaCl}\left(0.1 \mathrm{~mol} \mathrm{~L}^{-1}\right)$ 


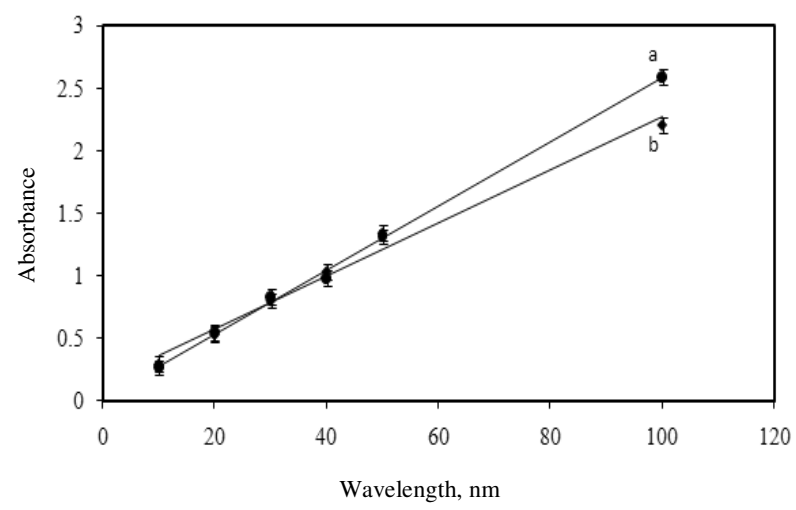

Figure 5. Calibration curves for MTX in the absence (a) and presence (b) of DNA at $298 \mathrm{~nm}$. Conditions: phosphate buffer $\left(0.1 \mathrm{~mol} \mathrm{~L}^{-1}, \mathrm{pH}\right.$ 7.4) plus $\mathrm{NaCl}\left(0.1 \mathrm{~mol} \mathrm{~L}^{-1}\right)$, $\mathrm{C}_{\mathrm{DNA}}=138.2 \mu \mathrm{mol} \mathrm{L}^{-1}$

\section{$M B-D N A$ interaction as a probe}

Absorption spectra of methylene blue dye in the absence of DNA showed three spectra bands at maximum wavelengths of 244, 290 and $662 \mathrm{~nm}$ (Figure 6). The absorbance at $662 \mathrm{~nm}$ gradually decreased with the increasing concentration of DNA and red shift was usually associated with molecular intercalation into the base stack of the DNA ${ }^{25}$. Those two observed spectral effects were attributed to a strong interaction between the electronic state of the intercalating chromophore and that of the DNA bases. The strength of this electronic interaction is expected to decrease as the third-order of the distance between the chromophore and the DNA bases ${ }^{26}$. The large observed hypochromism during the interaction of $\mathrm{MB}$ dye with ds-DNA, strongly suggest that the distance between the intercalated MB dye and DNA bases is small. Also an isobestic point at $281 \mathrm{~nm}$ demonstrates a new adduct between MB and DNA. Therefore methylene blue can be selected as a spectral probe for study the drug-DNA interactions. Because of the intercalation mechanism between $\mathrm{MB}$ and DNA, we used it as a probe for study the competitive interaction of MTX with DNA.

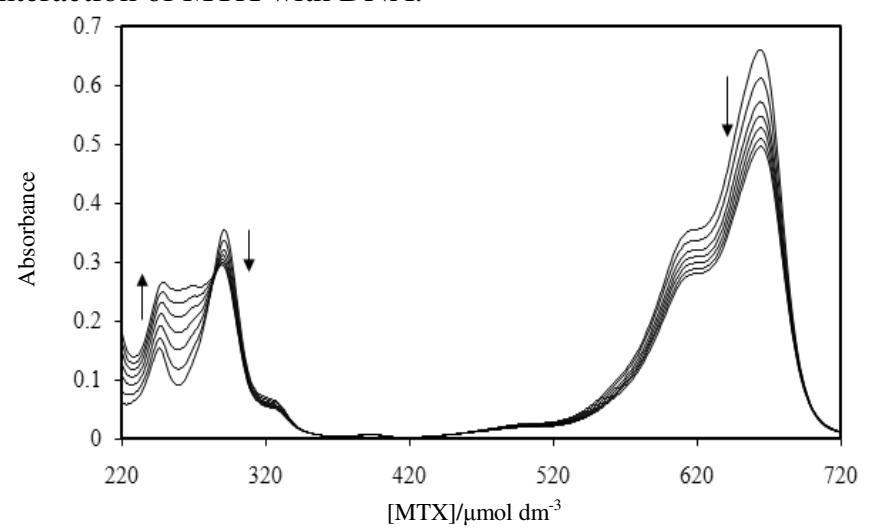

Figure 6. Absorption spectra of $\mathrm{MB}$ in the presence of DNA at different concentrations. $c_{\mathrm{DNA}}=0.0,5.3,10.0,14.8,19.1,23.0$ and $26.7 \mu \mathrm{mol} \mathrm{L} \mathrm{L}^{-1}$ for curves $1-7$ and $\mathrm{C}_{\mathrm{MB}}=100.0 \mu \mathrm{mol} \mathrm{L} \mathrm{L}^{-1}$ in phosphate buffer $\left(0.1 \mathrm{~mol} \mathrm{~L}^{-1}, \mathrm{pH} 7.4\right)$ plus $\mathrm{NaCl}\left(0.1 \mathrm{~mol} \bullet \mathrm{L}^{-1}\right)$ 


\section{Competitive interaction of MTX with MB-DNA}

A competitive interaction between MTX and MB-DNA system was studied by the addition of MTX to a solution containing methylene blue and DNA. As it is clearly shown in Figure 7, the intensity of the spectral band of MB-DNA at $662 \mathrm{~nm}$ does not change significantly. Also three new peaks related to methotrexate at about $256 \mathrm{~nm}, 269 \mathrm{~nm}$ and $292 \mathrm{~nm}$ appeared which increased progressively in intensity. According to the observations, it seems that no exchange take place between MTX and MB-DNA adduct. In addition unchanging in position of spectra band at $662 \mathrm{~nm}$ in the absence and presence of DNA suggests that MTX has a week interaction with double helix of DNA.

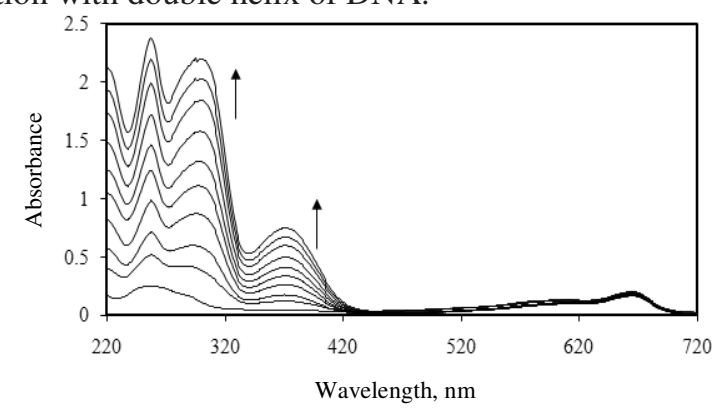

Figure 7. Absorption spectra of the competitive interaction between MTX and methylene blue bonded to DNA at $\mathrm{C}_{\mathrm{MTX}}=0.0,10.0,20.0,30.0,40.0,50.0,60.0,70.0,80.0$ and $90.0 \mu \mathrm{mol} \mathrm{L} \mathrm{L}^{-1}$ for curves $1-10, \mathrm{C}_{\mathrm{MB}}=20.0 \mu \mathrm{mol} \mathrm{dm}{ }^{-3}$ and $\mathrm{c}_{\mathrm{DNA}}=27.6 \mu \mathrm{mol} \mathrm{L} \mathrm{L}^{-1}$ in phosphate buffer $\left(0.1 \mathrm{~mol} \mathrm{~L}^{-1}, \mathrm{pH} 7.4\right)$ plus $\mathrm{NaCl}\left(0.1 \mathrm{~mol} \mathrm{~L}^{-1}\right)$

\section{Melting studies}

Heat and alkali can destroy the structure of methotrexate at the milting temperature $\left(\mathrm{T}_{\mathrm{m}}\right)$. Interaction of small molecules with DNA can influence $\mathrm{T}_{\mathrm{m}}$.. Intercalation binding can stabilize the molecular structure and Tm increases by about $5-8{ }^{\circ} \mathrm{C}$, but the non-intercalation binding causes no obvious increase in $\mathrm{T}_{\mathrm{m}}{ }^{27}$. The values of $\mathrm{T}_{\mathrm{m}}$ for MTX and DNA-MTX system were determined, respectively, by monitoring the maximum absorbance value of the system as a function of temperature ranging from $25{ }^{\circ} \mathrm{C}$ to $66^{\circ} \mathrm{C}$. The melting curves have shown in Figure 8. It can be seen that the $\mathrm{T}_{\mathrm{m}}$ of MTX in the absence and presence of DNA is about $60{ }^{\circ} \mathrm{C}$ under the experimental conditions.

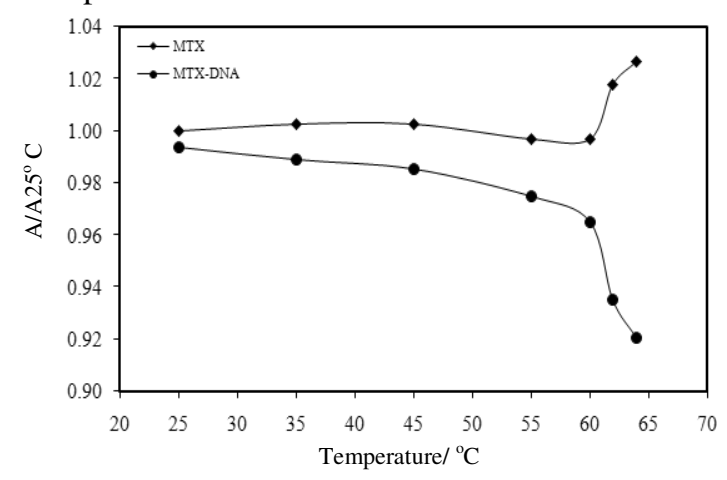

Figure 8. Melting curves for MTX in the absence and presence of DNA at $298 \mathrm{~nm}$. Conditions: $\mathrm{c}_{\mathrm{MTX}}=10.0 \mu \mathrm{mol} \mathrm{L}-1, \mathrm{C}_{\mathrm{DNA}}=55.3 \mu \mathrm{mol} \mathrm{L} \mathrm{L}^{-1}$ in phosphate buffer $\left(0.1 \mathrm{~mol} \mathrm{~L}^{-1}\right.$, $\mathrm{pH}$ 7.4) plus $\mathrm{NaCl}\left(0.1 \mathrm{~mol} \mathrm{~L}^{-1}\right)$ 


\section{Electrochemical studies}

\section{Interaction of MTX with ds-DNA in solution}

The electrochemical behavior of MTX in the absence and presence of DNA at bare GCE was studied by cyclic voltammetry. One oxidation peak for MTX was recorded at +0.85 V/SCE in pH 7.4 phosphate buffer. The absence of any peaks in the reverse scan revealed the irreversible nature of the process. The addition of DNA into the MTX solution caused a considerable diminish at peak current as shown in Figure 9.

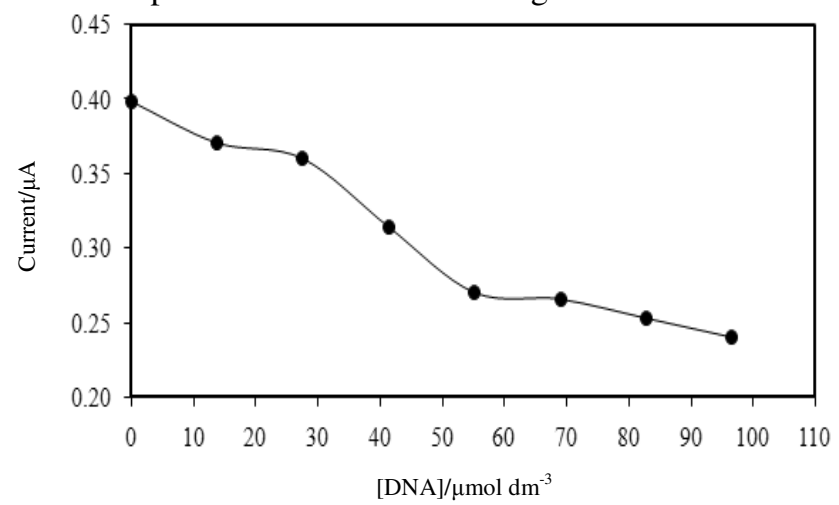

Figure 9. Dependence of peak current of MTX to DNA concentration. Conditions: $\mathrm{C}_{\mathrm{DNA}}=$ $0.0,13.8,27.6,41.5,55.3,69.1,82.9$ and $96.7 \mu \mathrm{mol} \mathrm{L}{ }^{-1}, \mathrm{C}_{\mathrm{MTX}}=50.0 \mu \mathrm{mol} \mathrm{L} \mathrm{L}^{-1}, \mathrm{v}=20.0 \mathrm{mV} \mathrm{s}^{-1}$

In order to demonstrate that the decrease in current was not due to the increased viscosity of solution or the blockage of the electrode surface by ds-DNA adsorption, a special cyclic voltammetry experiment was designed in a $\mathrm{K}_{4} \mathrm{Fe}(\mathrm{CN})_{6}$ solution with or without DNA. In these solutions, $\mathrm{Fe}(\mathrm{CN})_{6}{ }^{4-}$ ions do not interact with DNA because of coulombic repulsion between their negative charges. It was shown that the addition of DNA decreased the current slightly, and there was no shift in the peak potential. Therefore, there are only few effects of the change in viscosity (ds-DNA addition) on the diffusion and no significant obstruction on the glassy carbon surface from ds-DNA adsorption. Therefore the binding of MTX to DNA should lead to a significant decrease of peak current due to the formation of MTX-DNA adduct with very small diffusion coefficient ${ }^{28,29}$. This is obvious from the significant decrease in the slopes of linear Ip- $v^{0.5}$ plots in the absence and presence of DNA with the equations of Ip $=3.0 \times 10^{-6}$ $v^{0.5}+3.0 \times 10^{-7}$ and Ip $=2.0 \times 10^{-6} v^{0.5}-3.0 \times 10^{-7}$, respectively.

\section{Tafel plot analysis}

In order to determine the apparent transfer coefficients $(\alpha)$ and the number of electron transferred (n) of MTX in the absence and presence of DNA, the anodic Tafel plots of MTX and MTX-DNA on the surface of glassy carbon electrode was plotted using the cyclic voltammetry. By linear regression fit of the anodic Tafel plots, anodic Tafel slopes were determined, which were $3.51 \mathrm{~V} \mathrm{Dec}^{-1}$ and $4.16 \mathrm{~V} \mathrm{Dec}^{-1}$ for anodic peaks of MTX in the absence and presence of DNA respectively. Thus, the values of $n(1-\alpha)$ were calculated from the Tafel slopes, which were 0.19 and 0.25 for oxidation peaks of MTX and MTX-DNA adduct, respectively.

We have recognized that the exchange current can be written as:

$$
\log i_{o}=\log \left(n f A k_{0}\right)+(1-\alpha) \log C_{o}^{*}+\alpha \log C_{R}^{*}
$$


Where $\mathrm{i}_{0}$ is the exchange current and can be calculated from the intercept of the Tafel plot. Thus we note that: ${ }^{30}$

$$
\left(\frac{\partial \log i_{0}}{\partial \log C_{R}^{*}}\right)_{C_{R}^{*}}=\alpha
$$

By plotting the oxidation Tafel data at different concentrations of MTX in the absence and presence of ds-DNA, we calculated the apparent transfer coefficient $(\alpha)$ from equation (2), which were 0.84 and 0.80 for MTX and MTX-DNA respectively. Consequently the number of electron transfer was calculated as 1 . From these values, the diffusion coefficient of free $\operatorname{MTX}\left(\mathrm{D}_{0}\right)_{\mathrm{f}}$ was found to be $7.30 \times 10^{-6} \mathrm{~cm}^{2} \mathrm{~s}^{-1}$, whereas $\left(\mathrm{D}_{0}\right)_{\mathrm{b}}=3.4 \times 10^{-6} \mathrm{~cm}^{2} \mathrm{~s}^{-1}$ was calculated for the bound MTX- DNA adduct. For an irreversible reaction at $25^{\circ} \mathrm{C}$, the peak current (Ip) of MTX can be calculated ${ }^{31}$ as:

$$
\mathrm{I}_{\mathrm{p}}=\mathrm{B}\left[\left(\alpha \mathrm{n}_{\mathrm{a}}\right)_{\mathrm{f}}^{1 / 2} \mathrm{D}_{\mathrm{f}}^{1 / 2} \mathrm{C}_{\mathrm{f}}+\left(\alpha \mathrm{n}_{\mathrm{a}}\right)_{\mathrm{b}}^{1 / 2} \mathrm{D}_{\mathrm{b}}^{1 / 2} \mathrm{C}_{\mathrm{b}}\right]
$$

Where $B=2.99 \times 10^{5} n A v^{1 / 2}, A$ is the surface area of the working electrode, $C_{b}$ and $C_{f}$ represents the equilibrium concentration of MTX in the presence and absence of DNA and the total concentration of $\mathrm{AMX}, \mathrm{C}_{\mathrm{t}}$, is:

$$
\mathrm{C}_{\mathrm{t}}=\mathrm{C}_{\mathrm{f}}+\mathrm{C}_{\mathrm{b}}
$$
form: ${ }^{32,33}$

Based on Carter et al., the binding constant, K, can be expressed as the following

$$
K=\frac{C_{b}}{C_{f}\left(\frac{[N P]}{2 s}-C_{b}\right)}
$$

Where $s$ is the size of binding site in terms of binding pair (bp) and NP is DNA concentration. Making appropriate substitutions and eliminating $\mathrm{C}_{\mathrm{b}}$ and $\mathrm{C}_{\mathrm{f}}$ from Eq. (3), a new equation was obtained:

$$
I_{p}=B\left\{\left(\alpha n_{a}\right)_{f}^{1 / 2} D_{f}^{1 / 2} C_{t}+\left[\left(\alpha n_{a}\right)_{b}^{1 / 2} D_{b}^{1 / 2}-\left(\alpha n_{a}\right)_{f}^{1 / 2} D_{f}^{1 / 2}\right] \times\left[\frac{b-\left(b^{2}-\frac{2 K^{2} C_{t}[N P]}{s}\right)^{1 / 2}}{2 K}\right]\right\}
$$

Where $b=1+K c_{t}+K[N P] / 2 s$. Since $\mathrm{I}_{\mathrm{p}}, \mathrm{C}_{\mathrm{t}}$ and $[\mathrm{NP}]$ are experimentally measurable and $\left(\mathrm{an}_{\mathrm{a}}\right)_{\mathrm{f}},\left(\mathrm{an}_{\mathrm{a}}\right)_{\mathrm{b}}, \mathrm{D}_{\mathrm{f}}$ and $\mathrm{D}_{\mathrm{b}}$ have already been acquired as mentioned above, the binding constant $(\mathrm{K})$ and binding site size (s) of the MTX-DNA can be obtained from a nonlinear regression analysis of the experimental data $\left(\mathrm{I}_{\mathrm{p}}-[\mathrm{NP}]\right.$ plot) according to Eq. (6). For the binding curve (Figure 9), a nonlinear fit analysis yielded $\mathrm{K}=1.0 \times 10^{3} \mathrm{~mol}^{-1} 1 \mathrm{~L}$ and $\mathrm{s}=0.1 \mathrm{bp}$. Obviously, the interaction between MTX and the solution-phase ds-DNA was not as strong as some other aromatic compounds which could intercalate into DNA helix via large conjugated structures.

\section{Determination of viscosity}

One indication of DNA binding mode is the change in viscosity when a small molecule associates with DNA. Intercalative binding increases the length of DNA and the viscosity significantly, whereas groove binding typically has a smaller effect on viscosity ${ }^{34}$. Figure 10 reveals that the viscosity of MTX has not changed considerably by the addition of DNA up to 5.5 mole ratios $\left(\mathrm{C}_{\mathrm{DNA}} / \mathrm{C}_{\mathrm{MTX}}\right)$ while the viscosity of $\mathrm{MB}$ increased in the presence of DNA (Figure 11). 


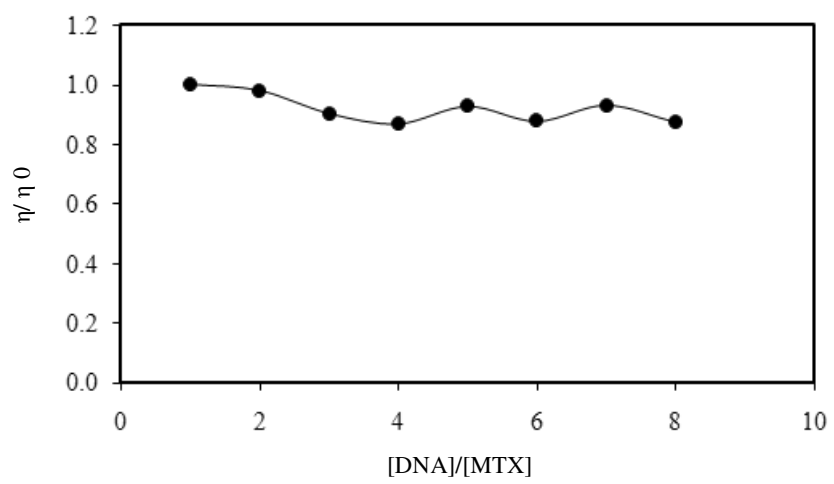

Figure 10. Effect of DNA on the viscosity of MTX solution $\mathrm{C}_{\mathrm{MTX}}=40.0 \mu \mathrm{mol} \mathrm{L}{ }^{-1}, \mathrm{C}_{\mathrm{DNA}}=55.3,82.9,110.56,138.2,165.8$ and $221.1 \mu \mathrm{mol} \mathrm{L}{ }^{-1}$ at $298 \mathrm{~K}$

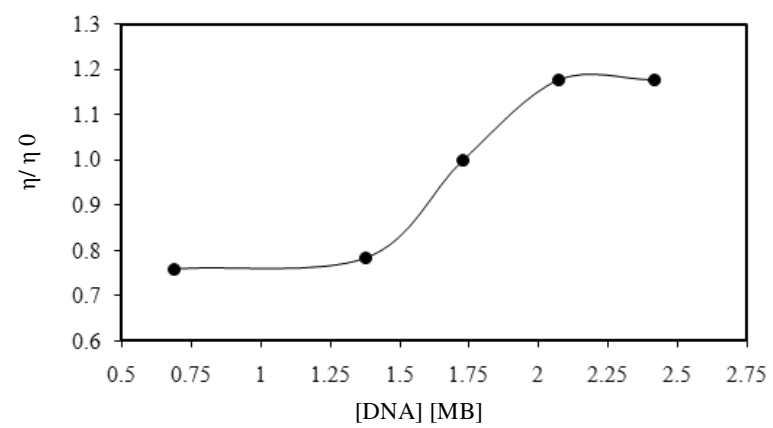

Figure 11. Effect of DNA concentration on the viscosity of MB $\left(40.0 \mu \mathrm{mol} \mathrm{L}{ }^{-1}\right)$

$$
\mathrm{C}_{\mathrm{DNA}}=27.6,55.3,69.1,82.9 \text { and } 96.7 \mu \mathrm{mol} \mathrm{L}^{-1} \text { at } 298 \mathrm{~K}
$$

Methotrexate is a weak dicarboxylic acid with pKa 4.8 and 5.5 and thus it is mostly ionized in the form of anionic at physiologic $\mathrm{pH}$. Therefore the electrostatic interaction between MTX and DNA is not possible. In conclusion, we propose a groove binding interaction between two adducts.

\section{Conclusion}

In this work, the interaction of MTX with DNA was studied by cyclic voltammetry, especially by various spectroscopic methods. The binding of MTX to DNA resulted in a series of changes in the electrochemical behavior and spectra characteristics. Upon binding to DNA, the absorptivity coefficient of MTX showed peculiar changes and the oxidation peak current of MTX was efficiently decreased. From these experimental results, it could be affirmed that the interaction of MTX with DNA is through non intercalative mode. Moreover, the small binding constant $\left(\mathrm{K}=1.0 \times 10^{3} \mathrm{~mol}^{-1} \mathrm{~L}\right)$ indicated MTX has a low affinity for the DNA base pairs. The electrostatic attraction between the anionic charge on MTX at pH 7.4 and the DNA phosphates is not expected to improve the DNA binding affinity. Therefore we suggest a groove binding interaction between two adducts. These investigations showed that electrochemistry coupled with spectroscopy techniques could provide a convenient way to characterize both the binding mode and the interaction mechanism of MTX binding to DNA, which is important for the design of new anticancer drugs. 


\section{Acknowledgement}

This work was supported by Research Council of Islamic Azad University branch of Gachsaran (IAUG).

\section{References}

1. Gilpin R K, Anal Chem., 1997, 69, 145.

2. Lerman L S, J Mol Biol., 1957-1961, 3, 18.

3. Waring M J, The Molecular Basis of Antibiotic Action, John Wiley and Sons, New York, United states, 1972, 173-227

4. Bertino J R, J Clin Oncol., 1993, 11, 5-14.

5. Ogimoto I, Shibata A and Fukuda K, Cancer Cause Control., 2000, 11, 9-23.

6. Endresen, G K and Husby G, Tidsskr Nor Laegeforen., 1999, 119, 534-7.

7. Ortiz Z, Shea B, Suarez-Almazor M E, Moher D, Wells G A and Tugwell P, J Rheumatol., 1998, 25, 36-43.

8. Jensen O K, Rasmussen C, Mollerup F, Christensen P B, Hansen H, Ekelund S and Thulstrup A M, J Rheumatol., 2002, 29, 1615.

9. Priebe W 1995 Anthracyclines Antibiotics. New Analogs, Methods of Delivery and Mechanisms of Action, American Chemical Society Washington DC, 1995,150

10. Dai X X, Li Y F, He W, Long Y F and Huang C Z, Talanta, 2006, 70, 578-83.

11. Li Y Q, Guo Y J, Li X F and Pan J H, Talanta, 2007, 71, 123.

12. Tong C L, Hu Z and Liu W P, Talanta., 2007, 71, 816.

13. Palaska P, Aritzoglou E and Girousi S, Talanta, 2007, 72, 1199-1206.

14. Ivandini T A, Honda K, Rao T N, Fujishima A and Einaga Y, Talanta, 2007, 71, 648-655.

15. Usacheva M N, Teichert M C and Biel M A, J Photochem Photobiol B., 2003, 71, 87.

16. Armstrong R W, Kurucsv T and Strauss V P, J Am Chem Soc., 1970, 92, 3174.

17. Erdem A, Kerman K, Meric B and Ozsoz M, Electroanal., 2001, 13, 219-223.

18. Ohuigin C, McConnell D J, Kelly J M and Van der Putten W J M, Nucl Acids Res., 1987, 15, 7411.

19. Fujimoto B S, Clendenning J B, Delrow J J, Heath P J and Schurr M, J Phys Chem., 1994, 98, 6633.

20. Kelly S O, Barton J K, Jackson N M and Hill M G, Bioconjugate Chem., 1997, 8, 31.

21. Britos L, Goyenola G and Orono S U, Biochem. Mol Biol Educ., 2004, 32, 341.

22. Yang P and Zhou C Q, Acta Chim Sinica, 2003, 61, 1455.

23. Ysoe S A, Baker A D and Strekas T C, J Phys Chem., 1993, 97, 1707.

24. Gao E J, Zhao S M, Liu Q T and Xu R, Acta Chim Sinica., 2004, 62, 593.

25. Long E C and Barton J K, Acc Chem Res., 1990, 23, 271.

26. Huang C Z, Li Y F and Feng P, Talanta, 2001, 55, 321.

27. Kumar C V, Turner R S and Asuncion E H, J Photochem Photobiol A Chem., 1993, 74, 231.

28. Shehatta I S and Ibrahim M S, Can J Chem., 2001, 79, 1431.

29. Aslanoglu M and Ayne G, Anal Bioanal Chem., 2004, 380, 658-63.

30. Bard A J and Faulkner L R, Electrochemical Methods Fundamentals and Applications, Wiley New York United States, 1980, 108.

31. Wang S F, Peng T Z and Yang C F, Biophys Chem., 2003, 104, 239.

32. Carter M T, Rodriguez M and Bard A J, J Am Chem Soc., 1989, 111, 8901.

33. Breslin D T, Coury J E, Anderson J R, McFail-Isom L, Kan Y Z, Williams L D, Bottomley L A and Schuster G B, J Am Chem Soc., 1997, 119, 5043-5044. 


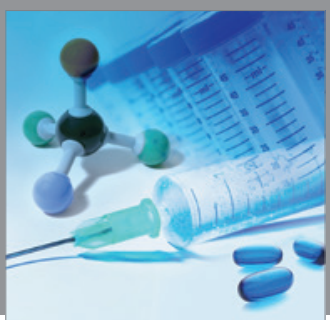

International Journal of

Medicinal Chemistry

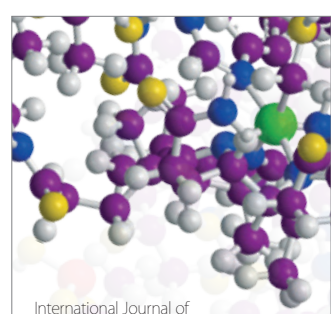

Carbohydrate Chemistry

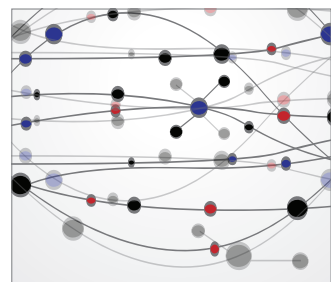

The Scientific World Journal
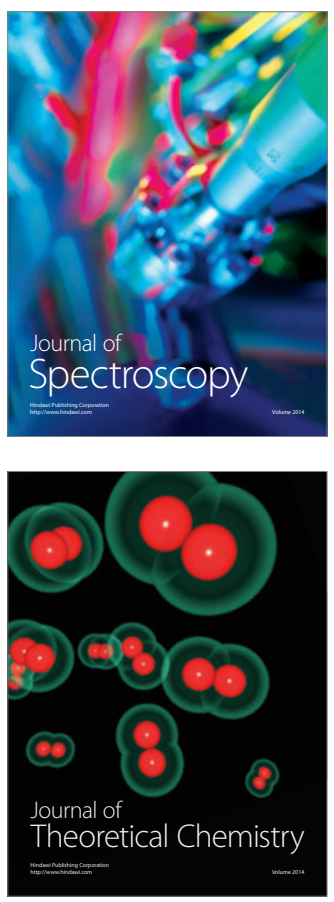
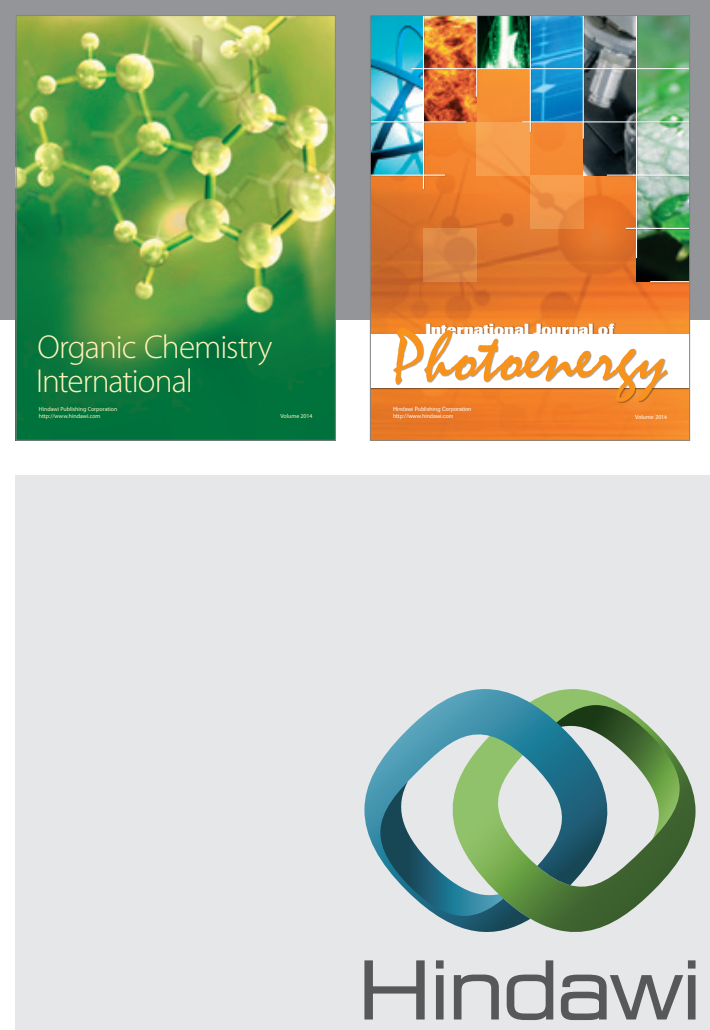

Submit your manuscripts at

http://www.hindawi.com
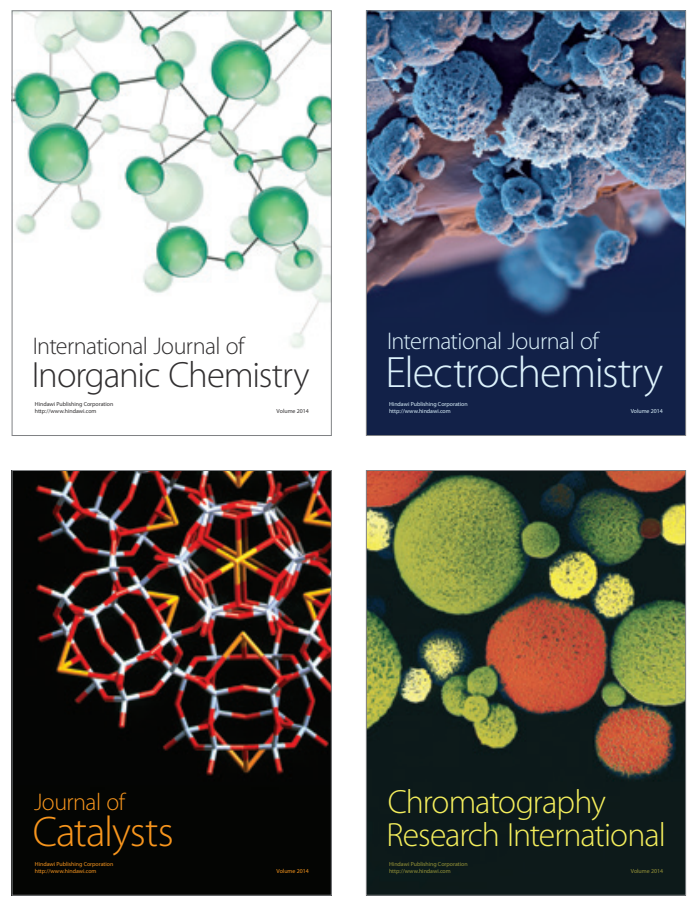
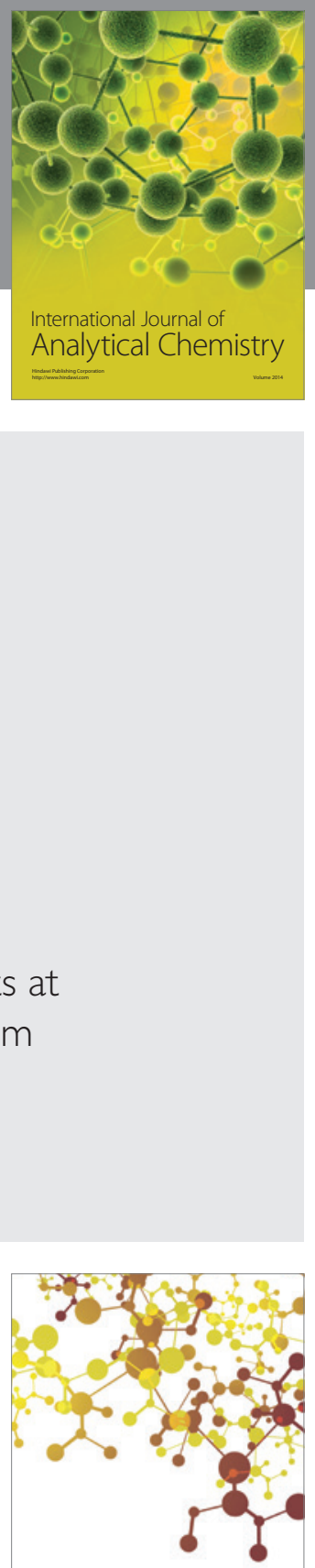

Journal of

Applied Chemistry
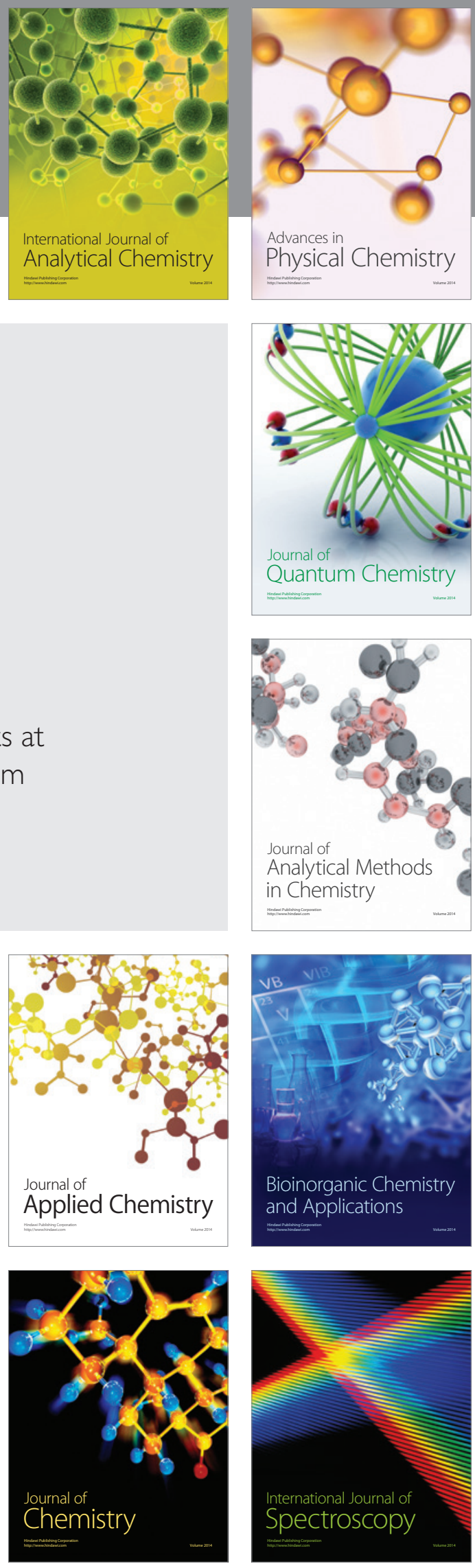